\title{
REFORMED ORTHODOXY IN PURITANISM
}

\author{
RANDALl J. PEDERSON" \\ Westminster Theological Seminary, Philadelphia
}

\begin{abstract}
This paper explores the relationship between early modern English Puritanism and Reformed orthodoxy through a fresh examination of three ministers who have been described as Puritans: John Owen, Richard Baxter, and John Goodwin. By assessing their attitudes toward the Bible and specifically the doctrine of justification, this paper uncovers an evolving consensus of orthodox thought in the period. Their attitudes and approaches to doctrine and church tradition led to diverse interpretations and directions in the codification of their religion. Their theological interpretations reflect an inherent pattern of diversity within English Puritanism, especially in its attitudes towards the formation of orthodoxy. The relation of Reformed orthodoxy to Puritanism, then, is more complex than older modes of scholarship have allowed. For the Puritan mainstream, Reformed orthodoxy served as a theological compass and thermostat that tested ideas and was to govern both the direction and temperament of Reformed doctrine. For those outside the pale, such orthodoxy and their alleged disloyalty to the Bible and Reformed church tradition was vehemently contested.
\end{abstract}

KEY WORDS: Puritanism, Reformed orthodoxy, Bible, doctrine of justification, theology

\section{Introduction}

In the last few decades there has been a transformation in understanding the nature and development of Reformed orthodoxy (Selderhuis 2013). ${ }^{1}$ While earlier studies had described the Reformation as a period of robust and vi-

RANDALL J. PEDERSON (PhD 2013, Leiden University) is managing editor of the Westminster Theological Journal, published by Westminter Theological Seminary, Philadelphia, Pennsylvania, United States of America. Email: rpederson@wts.edu.

1 While the term 'Reformed orthodoxy' refers to the codification of the Reformed religion following the Reformation from roughly 1550-1750, there are scholars who question its usefulness since 'orthodoxy and its opposites were very much in the eye of the beholder'. It is beyond the scope of this paper to delve into this issue, but the term Reformed orthodoxy does sufficiently express mainstream Reformed consensus in the age of confessions and is useful for understanding how the early modern Reformed defined and reinforced their spiritual identities. But with that said, by using the term I do not mean to suggest that there was absolute uniformity in doctrine and practice; indeed, as we shall see, even on the most basic and fundamental of Protestant doctrines there was disagreement. 
brant biblical exegesis, and the post-Reformation as one of decline into rationalism, the pioneering work of Richard Muller and those of his 'school' have initiated a rather dramatic turnaround in showing that the heirs of the Reformation were no less biblically robust in their exegesis, or pious in their lives, than those who went before them (Muller 2003; Muller 2012; Selderhuis 2013; Ballor 2013). Post-reformational advancements of precision in theology are now seen as an elaboration and development of the Protestant ideal, rather than as a deviance from it (Muller 2003; Van Asselt 2013; Denlinger 2014; Manetsch 2012: 241-5). Studies of this progression toward a thoroughly refined and scholastic orthodoxy-the codification of the Reformed faith in its creeds, symbols, and many theology manuals-have shed insight into Reformed sources and preoccupations in the period to such an extent that one can readily see a diverse wellspring of theological formation and cross-fertilization. ${ }^{2}$ It is, for instance, now established that Calvin was not the 'fountainhead' of Reformed religion, as though he were the sole architect of what came to be known as 'Calvinism', but rather was but one of many second-generation reformist voices singing to a Reformed tune (Fesko 2012: 26, 126-9). ${ }^{3}$ Moreover, the continental influence of the Reformation in Britain, and the formation and reception of orthodox thought in England, would not have been possible without the printing press, exile, and freedom to travel to the continent (Fudge 2007: 107ff; Ha 2011).

The English Puritan chorus in the Post-Reformation period, who generally espoused what we might call 'British Reformed orthodoxy', was equally robust and diverse (Muller 2011: 11-30). Indeed, many voices other than Calvin had effectively promoted Reformed virtues across England. This diversity of germination and proliferation of ideas, made possible by a burgeoning English learned book trade and promotion of standard divines (Downame 1629; Mather 1726), was doubtless responsible for the 'shifting patterns of Reformed tradition' we see in the period, which invariably resulted in competing stances on doctrine and practice, even though, by and large, there was great harmony in the fundamentals of religion and religious practice (Trueman 2013: 263). ${ }^{4}$ on biblical exegesis, can be seen in Leiden University's Synopsis Purioris Theologiae (16201624), originally a series of public disputations by Leiden's theology faculty (Johannes Polyander, Andreas Rivetus, Antonius Walaeus, Antonius Thysius) that sought to clarify important doctrinal matters. The disputations are now being republished in their original Latin with English translation (Te Velde 2015).

3 Though it is evident that the Reformed tradition was an eclectic one, some scholars still seem to perpetuate the myth that Calvin was 'standing at the fountain-head of the Reformed tradition', a standing Calvin himself denied (e.g. Gibson 2011; Helm 2014).

4 I am indebted to Emidio Campi for the phrase 'shifting patterns of Reformed tradition'. Though he uses it within a continental context, it is equally applicable to the English Reformed (Campi 2014).

PERICHORESIS 14.3 (2016) 
Within current scholarship, however, there is dissensus on the place of Reformed orthodoxy within Puritanism. Historically, attitudes have centered on a monolithic Puritanism that was synonymous with orthodox thought. Thus, the English Puritan was by definition 'orthodox', a belief promulgated by Perry Miller that still pervades certain sectors of scholarship (Miller 1953; Watts 1985). However, revisionists have questioned this view as naïve, simplistic, and untenable given the evidence, and have instead insisted that $\mathrm{Pu}-$ ritanism should not be defined by its 'mind' or orthodoxy, but by its impulse for spiritual reform, or 'in terms of a common outlook, ethos or culture' (Knight 1994; Winship 2002: 248; Trueman 2012: xii; Marshall 2012: 147). But, as Buchanan Sharp has pointed out, it is impractical to understand $\mathrm{Pu}$ ritanism solely, or even chiefly, in terms of its 'reformation of manners', because other spiritual reformists in the period had equally engaged in their own pursuit of moral purism (Sharp 1993: 257-8). Indeed, it would be difficult, if not impossible, to distinguish the precisianism and vigor of a Lancelot Andrewes from his Puritan counterparts, even though there were sharp disagreements between them on ceremonial conformity (Lake 1991; McCullough 2005: 332). The better path forward, as I will attempt to show in this paper, is to see Puritanism as a conglomerate of doctrine and manners that had a mainline expression, centered on a Reformed orthodox view of the Bible, its interpretation, and application to life, but which also, signaling its heterogeneity, embraced various doctrinal malcontents, who emerged from that tradition and challenged it, but who were nonetheless influenced and changed by it. Thus, I propose that we might distinguish between mainline Puritans who shared the doctrinal standards of Reformed orthodoxy and more marginal Puritans who deviated from (some of) these standards but nevertheless continued to be part of the Puritan movement because of their shared spirituality.

In order to understand the relationship between Reformed orthodoxy and Puritanism, and not fall into the error of monolithicism, ${ }^{5}$ this paper will briefly examine three diverse 'Puritans', their attitudes toward the Bible and their understanding of the 'pillar' of Protestant religion, the doctrine of justification. It will first examine John Owen, a theologian who typifies a rigorous and eclectic Reformed orthodoxy; it will then, second, assess Richard Baxter, a controversial divine and pedlar of Puritan divinity, whose later pub-

G. R. Elton once said that the aim of the student of history is 'to know all the evidence' that could pertain to one's inquiry (Elton 2002: 60). While it is impossible to assess and give diligence to everything, one ought to be aware of historical assumptions that exclude certain conclusions before the historical evidence is duly considered, such as, for the purposes of this paper, the presumption of a rigid orthodoxy in the seventeenth century. 
lishers redacted what they saw as his doctrinal infelicities. Third, it will consider the deviations of John Goodwin, a Puritan of a different sort; ${ }^{6}$ and, in conclusion, it will propose seeing Reformed orthodoxy as a refining and purifying process of the Puritan majority, which sought unity in an age of confessions, but did not necessarily expect uniformity; and finally it will briefly suggest a constructive path moving forward in this field of research.

We will now turn to John Owen, who has been described as one of the 'over-orthodox doctors' of Puritanism (Burton 2013: 31). ${ }^{7}$

\section{John Owen (1616-1683)}

Given his extensive corpus and status as a monolith of Reformed orthodoxy, there has been a resurgence of interest in John Owen in recent years, with monographs exploring facets of his thought and piety (Gribben 2016; Leslie 2015; McGraw 2014; Cleveland 2013; Kapic 2013; Trueman 2007). Owen had a formative influence on the course of mid-century Puritanism by refuting what he saw as errors in theology, having learned the practice of disputation while a student at Oxford University-but he was careful to distinguish 'fundamentals' from 'non-fundamentals' (Bearman 2010: 505; Coffey 2006: 129). Through his rigorous affective piety and theological precision, Owen, perhaps more than any other Puritan, epitomizes mainstream Reformed belief, practice, and dogmatics in the seventeenth century, and serves as an excellent reference for comparison. Thus, we will briefly assess Owen's attitude towards the Bible and its interpretation, examine his understanding of the doctrine of justification as a forensic act, and make some observatory remarks on how a mainstream Puritan viewed orthodoxy on a foundational doctrine. ${ }^{8}$

One of the hallmark features of Owen's thought is his dislike of abstruse philosophical terminology and reliance on biblical exegesis: Puritanism to be a conglomerate of ideas centered around a pietistic and reforming culture-a Puritan Reformation, if you will-then it is not inconceivable that those at the fringes might look different (and, in some cases, drastically different) from those at the epicenter, but still remain part of it.

7 The moniker is from Richard Baxter's autobiography, Reliquiae Baxterianae (1696), p 199, in which he complains about Owen adding terminology to 'obviate the Heresies and Errours of the Divines'. Baxter elsewhere criticizes the zeal of the overly orthodox as 'devilish' and 'satantical' while upholding orthodoxy himself (Baxter 1830: 14.169). I fully realize that the use of 'mainstream Puritan' is contested in scholarship. On the one hand, scholars reason that Puritanism was so diverse and multifaceted that there could be no 'mainstream'. On the other, and more accurate in my view, are those who insist that from its earliest roots there was a normative orthodoxy and practice that grew over time, and reached full expression and codification at the Westminster Assembly, but which also gave rise to all sorts of deviations during the English Revolution. Nonetheless, the term is useful to describe those who represented the mainline or orthodox consensus. 
I had rather, indeed, insist on the propriety of words in the originals, their use in the law and amongst men, so all be regulated by the analogy of faith, than square the things of God to the terms and rules of art and philosophy... Let any man living express any doctrine of the gospel whatever in the exactest manner, with artificial, philosophical terms, and I will undertake to show that in many things the truth is wrested and fettered thereby...' (Owen 1850-55: 12.610-11).

In fact, for Owen, biblical truth plainly stated was of primary importance for doctrine and life. He expressed his thoughts on proper exegesis in his Synesis Pneumatike. The Causes, Ways, and Means of Understanding the Mind of God (1678), a popular text that argues for the foundational role of Scripture and the ability of all believers to interpret it aright. Here Owen advocates for a 'two springs' approach to the Bible: the testimony of the church and the testimony of the Holy Spirit. While Owen sees merit to the pursuit of scholarly disciplines, such as the use of original languages and familiarity with the ancient world (a humanist approach), and even expresses his own indebtedness to church tradition, such aids are 'ancillary' to the Bible because they do not always evince consensus or universal agreement (Amos 2015: 116-23; Muller 2000; Owen 1678; Tweeddale 2011: 56-7). The only source of final authority, then, is the Bible, and the only reliable way to find sound doctrine is through a vigorous exegesis of the biblical text that is guided by the 'Spirit of Truth', through whose operations and illumination a believer is guided to the correct interpretation (Owen 1678). Owen does not state that the Bible is clear in all places (some passages of Paul are notoriously difficult), but that it is perspicuous in matters of faith and manners for every believer (Owen 1678: 5; Gordis 2003: 18-23).

There is some irony to the fact that the foremost Protestant doctrine, the doctrine of justification by faith, was so hotly contested among the 'orthodox' in the English Church. For instance, Owen said the doctrine was 'of the highest importance to the Souls of men', while acknowledging divisions among the orthodox over it (Owen 1677). Though there was an established Protestant consensus early on, at least in terms of the remission of sins, there were varieties of opinion in how and when this remission was applied to a sinner. Was it from eternity? Was it before faith? Was it conditional? Did it happen at the moment of conversion? On what grounds was one justified?

Owen's mature view of the doctrine, The Doctrine of Justification by Faith (1677), birthed from his own careful linguistic and exegetical study of the Bible, and forged in his earlier debates with Roman Catholics, Socinians, and Arminians, represents a forensic view that was shared by most of the Reformed orthodox theologians (Trueman 2007: 101-22). Here Owen argues for a single act of unconditional justification in contradistinction of a double act as espoused by Roman Catholics (Leslie 2015: 112; Trueman 2007). The 
process is immediate and unconditional, rather than contingent upon continued obedience and a lifelong process of being justified. Owen also sees the imputation of Christ's active and passive righteousness as the formal cause of justification before God, not one's faith (Owen 1677: ch. 7, 9). He sees sanctification as the fruit of justification, and argues that once received, justification cannot be lost (Owen 1677: 201-4, 210-11). Further, Owen rejects the doctrine of justification from eternity, as well as the related view that justification takes place before someone has come to faith. In this, he distances himself from the views of William Twisse, William Pemble, and William Eyre. There is some question whether the doctrine of justification from eternity was outside the pale of Reformed orthodoxy. While most Reformed confessions make no pronouncement on it, and many prominent divines held to this view, even though it was associated with antinomism, the Westminster Assembly did conclude as a matter of orthodoxy that believers justified at the moment of their conversion. In fact, Chad van Dixhoorn has suggested that antinomism was a greater and more immediate fear to the Assembly than Catholicism (Van Dixhoorn 2009).

Owen's belief in the primacy of the Bible, and his optimism for its proper interpretation for faith and morals, is typical of the Protestant and Puritan mind. His treatment of the doctrine of justification as a forensic act of imputation is a standard statement of Reformed orthodoxy. Though consensus on the doctrine was neither universal (especially in dialogue with those outside orthodox circles), nor easy to come by, except, perhaps, for a basic assumption that saw justification as a divine act that remitted sins, mainline Puritans fought for a standard use of words and expressions, and thus meaning, that guarded against doctrinal error and misunderstanding. They sought to balance objective truth with subjective experience; thus the doctrine of justification was a consoling doctrine that was used for pedagogical and pastoral purposes. But the doctrine was also frequently discussed in polemical discourses: the specter of antinomism, synergism, and socinianism was always in the background of Reformed Orthodox discussions of it, as seen in the so-called 'free grace' controversy of the 1630-1640s (Winship 2002).

In contrast to the forensic view defended and clarified by Owen is that of Richard Baxter, and to him we will now turn.

\section{Richard Baxter (1615-1691)}

Baxter was an English pastor, theologian, poet, and polemicist, best known for his writings on heaven and the Christian life. Given that his popularity rests almost entirely on his practical writings, which were republished in the nineteenth century, the portrait of Richard Baxter portrayed in the literature is often distorted and does not give consideration to the overall tenor of his work and theology; indeed, as Cooper reminds us, Baxter could be 'rude, 
arrogant, tactless, sharp, and offensive'; though desirous of true peace among the brethren, 'his methods invariably extended controversy and provoked further division and argument, from the very beginning to the very end' (Cooper 2012: 55-6).

Though the literature on Baxter is immense, no one, to my knowledge, has ever attempted to discredit Baxter as 'Puritan'. Largely self-educated (Baxter 1696: 1.85), Baxter has often been referred to as the father or precursor of the neonomian strain within Puritanism, one that saw the gospel as a 'new law' that ought to be obeyed by faith and repentance (Daniel 1997: 177). Lim even goes so far as to call Baxter the 'father of Unitarianism', even though Baxter held to a classically orthodox view of the Trinity (Lim 2012: 247). Regardless, Baxter's legal emphasis in English theology was in response to his exposure to antinomism during the English Civil Wars (Cooper 2001). For much of his life, Baxter was caught in controversy over his assertion that the believer contributed evangelical righteousness to his redemption (Burton 2012: 337).

Here we will comment on Baxter's view of the Bible, his understanding of the doctrine of justification by faith, and conclude with a few remarks on his status as an orthodox divine.

For Baxter, only that which is plainly taught in Scripture should be required of Christians. Though knowledge of the Bible may vary, clergy should pursue a thorough knowledge of doctrine and tradition, with church unity centered on the fundamentals of Christian religion as expressed in the Apostle's Creed and Niceno-Constantinopolitan Creed (Baxter 1830: 4.687-9; Baxter 1653: 3; Edwards 2009: 93). As with Owen, Baxter finds knowledge of the original languages, church tradition, and scholastic methodology useful for interpreting Scripture; in fact, he himself had acquired an impressive library of medieval exegetical and theological titles, which he frequently cites in his writings (Trueman 2011: 60). Whatever learning one obtained, either through classical education or through self-study, it was the Bible that should have the pre-eminence (Baxter 1830: 1.57).

Controversy over Baxter's doctrine of justification, representing one of the 'bitter battles among the Reformed', arose when Baxter published his Aphorismes of Justification in 1649, a work he penned primarily for the edification of his church at Kidderminster (Muller 2003: 1.76; Muller 1980: 30834). It is possible that the humility with which Baxter published his work, seeking the approval of other divines, helped to mitigate the heat of the controversy (Baxter wrote, 'If you approve, I shall be the more conformed... If you disallow... I shall suspect, and search again' [Baxter 1655]), but regardless of his intent or irenicism, the result was an intellectual rupture among the Reformed orthodox (Muller 2003: 1.76). 
In contrast to Owen's forensic doctrine of double imputation, where Christ's righteousness is imputed to the sinner and the sinner's unrighteousness to Christ, Baxter argues for a Grotian view that differs markedly in that it denies the strict imputation of Christ's righteousness and instead holds that believers must have their own inherent 'evangelical righteousness' that fulfills the Covenant of Grace through faith and repentance and thus 'merits' its benefits (Baxter 1655: 62-75). His rejection of the orthodox view drew immediate ire and tarnished his reputation into subsequent centuries, causing him to be a bete noire on the doctrine (Boersma 1993).

Baxter's views were birthed in what he saw as antinomian crisis in the English Church. His attitude toward the Bible as an infallible rule of doctrine and life was such that he searched for and found relief from the specter of antinomism in the biblical text itself. As a precisianist, Baxter feared that antinomian doctrine would lead to immorality and social disorder, but he went further in his interpretation of justification than other Reformed orthodox divines by pressing the importance of faith and repentance as meritorious 'works'. In this, he appears to have more in common with the Arminian ideas circulating in his day than with that of the Reformed. In fact, Baxter has often been called 'Arminian' in his thinking (Packer 2003; Lamont 1979; Neve 1931: 153), but has nonetheless retained his status as a Reformed Orthodox divine (Ballor 2013).

We will now turn to John Goodwin, a minister who has been described as a Puritan. By sketching Goodwin, we will better see what distinguishes the Reformed Orthodox Puritan from the unorthodox.

\section{John Goodwin (1594-1665)}

While it is debated whether Goodwin should be classified as 'Puritan', with some scholars excluding him from the Puritan fold, and others arguing that he had merely modified Puritanism (Webster 1987: 39-58; Webster 1997: 147), here, as with Owen and Baxter, we will show from Goodwin's view of the Bible, use of church tradition, and beliefs concerning the doctrine of justification that though he wasn't a mainline Puritan, he can still be seen as part of the wider Puritan movement; we will then briefly comment on what distinguishes him from the Reformed Orthodox, and then conclude the paper.

Goodwin, an independent divine and vicar of a prominent Puritan parish in London, St. Stephens, Coleman Street, with connections among the socalled 'disaffected' (Coffey 2006: 10) was educated at Christ's College, Cambridge, in the humanist and scholastic traditions, and began his ministry with little fanfare, but soon after came under attack for various positions that were deemed controversial or unorthodox (Coffey 2006: 13-43; Parnham 2014). Because of his intellectual rigor he has been described as a critic of intellec- 
tual inertia'. A prolific author, Goodwin's writings evince a divine who, similar to Owen and Baxter, was well-versed in the original languages, church tradition (Goodwin interacted with the leading Protestant commentaries of his day), Aristotelian logic, and the methods of scholasticism (Coffey 2006: $34)$.

Goodwin's views of the Bible, which he sees as the sole authoritative text in his writings, are laid out, in part, in his book, The Divine Authority of the Scriptures Asserted (1645). Here Goodwin refutes what he calls the 'antiscripturalism' of his age, by which he means the constant bickering among the 'godly' over various interpretations of the biblical text. Originating as a series of sermons, Divine Authority was an attempt to restore confidence in the Bible against questions about its reliability, perspicuity, and authority. Divine Authority upholds the Bible as the providentially persevered message of Jesus Christ, and as the 'foundation of Christian religion', from which doctrine, orthodoxy, the way of salvation flow (Goodwin 1645: 15, 17-22). As Coffey points out, Divine Authority was 'tailored to appeal to committed (if troubled) Christians', who opted for a more traditional approach to the Word, one in which laity 'listened respectfully as the Word was expounded by orthodox and learned divines' (Coffey 2006: 154). Thus, in his doctrine of Scripture, Goodwin does not seem to deviate from the Reformed orthodox and adopts a traditionally Protestant position.

Goodwin's Treatise of Justification (1642), which we will now turn to, further evinces his skill in biblical exegesis, humanism, and scholasticism. In fact, the book rests on his exegesis of the Bible, especially the Greek New Testament. Here Goodwin interacts with Ames, Calvin, Vermigli, Bucer, Paraeus, Musculus, Junius, Aainsworth, and Grotius (Coffey 2006: 31). Goodwin's skill as a humanist and wit with words was so well known that even John Owen felt he had to acknowledge it (Owen 1850-53: 11.14).

Goodwin's view of the doctrine of justification departs from Reformed orthodoxy by rejecting the doctrine of Christ's double imputation. Here he criticizes other divines for adhering to 'those misprisions and mistakes of our first Reformers', and teaching them 'for Doctrines and Orthodox truths... As if it were not lawful to think that there may be more light in the air when the sun is risen in his might upon the earth, then there was at the first dawning and breaking of day' (Goodwin 1642). Goodwin argues that sinners are declared righteous on account of Christ's sacrifice as a sin-offering, but without the imputation of Christ's merits; here he claims support from various Reformed divines (Goodwin 1642: 83). While Baxter also rejects the orthodox view of imputation, Goodwin went further by not only promoting a form of universal redemption, where Christ is said to have died for all equally (not merely sufficiently), but by also opening up the possibility that a justified saint 
could lose his or her salvation (Goodwin 1651), a view condemned by the Reformed Orthodox (Owen 1654; Quantin 2009: 258-60).

It was Goodwin's active promotion of 'intellectual radicalism' and his Arminian views on justification and perseverance that pushed him beyond the pale of Reformed orthodoxy, and thus mainline Puritanism, though not necessarily from Puritanism itself. Indeed, Goodwin was deeply influenced by a wide range of reading from continentally Reformed sources to the writings of Dutch Arminians and Italian humanist reformers. Among the Arminians, he showed particular fondness for Hugo Grotius; and though he rarely quoted Arminian works directly, he was nonetheless acquainted with them, even admitting that he had read Arminius and consulted the works of Arminius's followers, where he found little difference between Arminius and 'the judgments and expressions of some Reformed churches', but profound difference with Arminius's followers (Goodwin 1647: 104; Coffey 2006: 34; More 1982: 50-70; Foster 1923: 1-37). Goodwin's theological influences, interpretations, and synergistic impulses pushed him into directions the Reformed orthodoxy vehemently opposed. Though he retained much of Puritanism's ethos and culture, he abandoned its confession; though a Puritan, he was a Puritan of a different sort.

\section{Conclusion}

While historical attitudes on the relation between Reformed orthodoxy and Puritanism have varied, the three ministers whose beliefs we have sketched show that the relation is neither synonymous nor mutually exclusive. All three shared a reverence for the Bible as 'that grand standard and test' for orthodoxy; all were skilled exegetes, and all honored the church's doctrinal tradition. But they came to diverse interpretations on the minutiae of the most fundamental Protestant doctrine. It was their own personal exegesis, their varied use of church tradition (whether patristic, medieval, continentally Reformed, or Remonstrant), and their interpretations of received texts that pushed them into the direction of Reformed orthodoxy or away from it.

For the mainstream Puritan, Reformed orthodoxy was a way to refine doctrine and come to some sort of standard belief and test whereby others were judged. However, it is evident that conceptions of a 'rigid' orthodoxy, in which doctrinal deviations or variations were not allowed, ought to be rejected in favor of a view in which Reformed orthodoxy was to some extent malleable; indeed, that Baxter could dissent and make evangelical righteousness a condition for justification and still be counted among the orthodox 'godly' shows that there was more consideration given to a divine's overall tenor than just doctrinal exactness or compliance with the prevailing consen- 
sus. But it is also true that one could, and in the case of Goodwin did, transgress orthodox sentiment to such as extent that he could no longer be considered Reformed or Reformed Orthodox, but still be a 'Puritan'.

While questions remain as to how Arminianism and Puritanism could coexist, much less coalesce, in Goodwin, future studies of this relation should prove beneficial in understanding the ethos and theological culture of Puritanism in its mainstream and more radical expressions. The unity in diversity that can be seen at the center becomes blurred at the edges. Minimally, the examples of Owen, Baxter, and Goodwin show that Reformed orthodoxy in Puritanism is much more complex than earlier studies, especially parochial ones, have allowed.

\section{Bibliography}

Amos NS (2015) Bucer, Ephesians, and Biblical Humanism. The Exegete as Theologian. New York, NY: Springer.

Ballor JJ (2013) The Shape of Reformed Orthodoxy in the Seventeenth Century. The Soteriological Debate Between George Kendall and Richard Baxter. In Ballor J, Sytsma D, and Zuidema J (eds) Church and School in Early Modern Protestantism. Studies in Honor of Richard A. Muller on the Maturation of a Theological Tradition. Leiden: Brill.

Ballor JJ, Sytsma D, Zuidema J (2013) Church and School in Early Modern Protestantism. Studies in Honor of Richard A. Muller on the Maturation of a Theological Tradition. Leiden: Brill.

Baxter R (1655) Aphorismes of Justification. London.

Baxter R (1696) Reliquiae Baxterianae. London.

Baxter R (1830) The Practical Works of the Rev Richard Baxter. London: James Duncan.

Boersma H (1993) A Hot Peppercorn. Richard Baxter's Doctrine of Justification in It Seventeenth-Century Context of Controversy. Zoetermeer: Boekencentrum.

Burgess G et al (2007) English Radicalism, 1550-1850. Cambridge: Cambridge University Press.

Burton SJG (2012) The Hallowing of Logic. The Trinitarian Method of Richard Baxter's Methodus Theologiae. Leiden: Brill.

Campi E (2014) Shifting Patterns of Reformed Tradition. Göttingen: Vandenhoeck \& Ruprecht.

Capp BS (2012) England's Culture Wars. Puritan Reformation and Its Enemies in the Interregnum, 1649-1660. Oxford: Oxford University Press.

Cleveland C (2013). Thomism in John Owen. Aldershot: Ashgate.

Coffey J (2006) John Goodwin and the Puritan Revolution: Religion and Intellectual Change in Seventeenth-Century Puritanism. Woodbridge: The Boydell Press. 
RANDALl J. PEDERSON

Coffey J (2006) A Ticklish Business. Defining Heresy and Orthodoxy in the Puritan Revolution. In Loewenstein D and Marshall J (eds) Heresy, Literature, and Politics in Early Modern English Culture. Cambridge: Cambridge University Press.

Cooper T (2012) Richard Baxter. In Sullivan GA and Stewart A (eds) The Encyclopedia of English Renaissance Literature. Malden: Wiley-Blackwell.

Cooper T (2001) Fear and Polemic in Seventeenth-Century England. Richard Baxter and Antinomianism. Aldershot: Ashgate.

Daniel C (1997) John Gill and Calvinistic Antinomianism. In Haykin MAG (ed) The Life of John Gill (1697-1771). A Tercentennial Appreciation. Leiden: Brill.

Denlinger AC (2014) Reformed Orthodoxy in Scotland. Essays on Scottish Theology, 1560-1775. New York: Bloomsbury.

Downame J (1629) A Guide to Godliness, or a Treatise of the Christian Life. London.

Edwards RM (2009) Scriptural Perspicuity in the Early Modern English Reformation in Historical Theology. New York, NY: Peter Lang.

Elton GR (2002) The Practice of History, second edition. Oxford: Blackwell.

Fesko JV (2012) Beyond Calvin. Union with Christ and Justification in Early Modern Reformed Theology, 1570-1700. Göttingen: Vandenhoeck \& Ruprecht.

Foster HD (1923) Liberal Calvinism. The Remonstrants at the Synod of Dort in 1618. Harvard Theological Review 16(1): 1-37.

Fudge JD (2007) Commerce and Print in the Early Reformation. Leiden: Brill.

Gibson D (2011) Reading the Decree. Exegesis, Election, and Christology in Calvin and Barth. New York: Bloomsbury.

Goodwin J (1642) Imputatio Fidei. Or, The Doctrine of Justification. London.

Goodwin J (1645) The Divine Authority of the Scriptures. London.

Goodwin J (1647) Apolnirōsis Apolnirōseōs. Redemption Redeemed. London.

Goodwin J (1647) Hagiomastix. London.

Gordis LM (2003) Opening Scripture. Bible Reading and Interpretive Authority in Puritan New England. Chicago, IL: University of Chicago Press.

Gribben C (2016) John Owen and English Puritanism. Experiences of Defeat. Oxford: Oxford University Press.

Ha P, Collinson P (2011) The Reception of Continental Reformation in Britain. New York, NY: Oxford University Press.

Haykin M (1997) The Life of John Gill (1697-1771). A Tercentennial Appreciation. Leiden: Brill.

Haykin M, Jones M (2011) Drawn into Controversie. Reformed Theological Diversity and Debates within British Puritanism. Göttingen: Vandenhoeck \& Ruprecht.

Helm P (2014) Faith, Form, and Fashion. Eugene, OR: Cascade Books. Jackson T (1872) The Life of John Goodwin. London.

PERICHORESIS 14.3 (2016) 
Kapic KM, Jones M (2012) The Ashgate Research Companion to John Owen's Theology. Aldershot: Ashgate.

Knight J (1994) Orthodoxies in Massachusetts. Rereading American Puritanism. Cambridge, MA: Harvard University Press.

Lake P (1991) Lancelot Andrewes, John Buckeridge, and avant-garde conformity at the court of James I. In Peck LL (ed) The Mental World of the Jacobean Court. Cambridge: Cambridge University Press.

Lamont W (1979) Richard Baxter and the Millennium. Protestant Imperialism and the English Revolution. Totowa: Rowman \& Littlefield.

Leslie AM (2015) The Light of Grace. John Owen on the Authority of Scripture and Christian Faith. Göttingen: Vandenhoeck and Ruprecht.

Lim PCH (2012) Mystery Unveiled. The Crisis of the Trinity in Early Modern England. New York, NY: Oxford University Press.

Loewenstein D, Marshall P (2006) Heresy, Literature, and Politics in Early Modern English Culture. Cambridge: Cambridge University Press.

Manetsch SM (2012) Calvin's Company of Pastors: Pastoral Care and the Emerging Reformed Church, 1536-1609. New York, NY: Oxford University Press.

Marshall P (2012) Reformation England, 1480-1642, second edition. London: Bloomsbury.

Mather C (1726) Manuductio ad Ministerium. Boston.

McCullough P (2005) Lancelot Andrewes. Selected Sermons and Lectures. New York, NY: Oxford University Press.

McCullough P, Adlington H, Rhatigan H (2011) The Oxford Handbook of the Early Modern Sermon. New York, NY: Oxford University Press.

McGraw RM (2014) A Heavenly Directory. Trinitarian Piety, Public Worship, and a Reassessment of John Owen's Theology. Göttingen: Vandenhoeck and Ruprecht.

Miller P (1953) The New England Mind. From Colony to Province. Cambridge, MA: Harvard University Press.

More E (1982) John Goodwin and the Origins of the New Arminianism. Journal of British Studies 22(1): 50-70.

Muller RA (1980) Covenant and Conscience in English Reformed Theology. Three Variations on a 17 th Century Theme. Westminster Theological Journal 42(2): 308-34.

Muller RA (2003) After Calvin. Studies in the Development of a Reformed Tradition. Oxford: Oxford University Press.

Muller R (2003) Post-Reformation Reformed Dogmatics. Grand Rapids, MI: Baker Academic.

Muller R (2011) Diversity in the Reformed Tradition. In Haykin MAG and Jones M (eds) Drawn into Controversie. Reformed Theological Diversity and Debates within British Puritanism. Göttingen: Vandenhoeck \& Ruprecht. 
RANDALl J. PEDERSON

Muller RA (2012) Calvin and the Reformed Tradition. On the Work of Christ and the Order of Salvation. Grand Rapids, MI: Baker Academic.

Muller RA, Thompson JL (2000) Biblical Interpretation in the Era of the Reformation. Grand Rapids, MI: Eerdmans.

Neve JL (1931) Arminianism in its influence upon England. Bibliotheca Sacra 88.

Owen J (1654) The Doctrine of the Saints Perseverance Explained and Confirmed. Oxford.

Owen J (1677) The Doctrine of Justification by Faith. London.

Owen J (1678) Synesis Pneumatike. The Causes, Ways, and Means of Understanding the Mind of God. London.

Owen J (1850-53) The Works of John Owen, edited by W. H. Goold. London: Johnstone \& Hunter.

Packer JI (2003) The Redemption and Restoration of Man in the Thought of Richard Baxter: A Study in Puritan Theology. Vancouver: Regent College.

Parnham D (2014). Heretics Within. Anthony Wotton, John Goodwin, and the Orthodox Divines. Eastbourne: Sussex Academic Press.

Peck LL (1991) The Mental World of the Jacobean Court. Cambridge: Cambridge University Press.

Pederson R (2014) Unity in Diversity. English Puritans and the Puritan Reformation, 1603-1689. Leiden: Brill.

Quantin JL (2009) The Church of England and Christian Antiquity. The Construction of Confessional Identity in the 17th Century. New York, NY: Oxford University Press.

Richardson RC (1993) Town and Countryside in the English Revolution. Manchester: Manchester University Press.

Selderhuis HJ (2013) A Companion to Reformed Orthodoxy. Leiden: Brill.

Sharp B (1993) Rural Discontents and the English Revolution. In Richardson RC (ed) Town and Countryside in the English Revolution. Manchester: Manchester University Press.

Te Velde D (2015) Synopsis Purioris Theologiae, volume 1. Leiden: Brill.

Traill R (1692) A Vindication of the Protestant Doctrine Concerning Justification. London.

Trueman CR (2007) John Owen. Reformed Catholic, Renaissance Man. Aldershot: Ashgate.

Trueman CR (2011) Preachers and Medieval and Renaissance Commentary. In McCullough P, Adlington H, Rhatigan E (eds) The Oxford Handbook of the Early Modern Sermon. New York, NY: Oxford University Press.

Trueman CR (2012) Preface. In Kapic KM and Jones M (eds) The Ashgate Research Companion to John Owen. Aldershot: Ashgate.

Trueman CR (2013) Reformed Orthodoxy in Britain. In Selderhuis H (ed) A Companion to Reformed Orthodoxy. Leiden: Brill.

PERICHORESIS 14.3 (2016) 
Van Asselt WJ (2013) Reformed Orthodoxy. A Short History of Research. In Selderhuis H (ed) A Companion to Reformed Orthodoxy. Leiden: Brill.

Van Dixhoorn C (2009) The Strange Silence of Prolocutor Twisse. Predestination and Politics in the Westminster Assembly's Debate over Justification. Sixteenth Century Journal 40(2): 405-6.

Watts MR (1985) The Dissenters. From the Reformation to the French Revolution. New York, NY: Oxford University Press.

Webster T (1987) Strange Bedfellows. Oliver Cromwell, John Goodwin, and the Crisis of Calvinism. Church History 56(1): 39-58.

Webster T (1997) Godly Clergy in Early Stuart England. The Caroline Puritan Movement, c.1620-1643. Cambridge: Cambridge University Press.

Winship MP (2002) Making Heretics. Militant Protestantism and Free Grace in Massachusetts, 1636-1641. Princeton, NJ: Princeton University Press. 